\title{
Opportunities of Reintegrating Refugees among Host communities in Tanzania
}

\author{
Timothy Asasira \\ Lecturer, Faculty of Development Studies and Management \\ Kampala International University, Dar-es-Salaam Tanzania \\ Email: timoasa@gmail.com
}

Received: May 27, 2012 Accepted: June 18, 2012 DOI: 10.5296/jpag.v2i2.2041

\begin{abstract}
This study focused on the Opportunities of Reintegrating Refugees among Host communities in Chogo refugee settlement, Handeni district, Tanzania. The study found out that Reintegration has led to the following; promotion of dialogue between refugees and the host communities and change of perception and attitude towards refugees as they are considered naturally violent. Issues on resource sharing, capacity building extension workers, ensuring basic services of equality as those available for host authority populations are provided to the refugees, developing a range of options with levels of self-help and related costs and loans relative to sanitation as they explore opportunities brought about by refugees such as education and other basic needs like water. The study makes the following, recommendations. That states the ministry of home affairs should enforce the acquisition of citizenship by some of these refugees who are reluctant to acquire citizenship claiming that they want to keep enjoying the privileges until they are repatriated back home. In the long run, the government should consider sensitization programmes among refugees and the host community towards the opportunities of reintegration rather than allocating the integrated refugees land only. More so, the government of Tanzania should pay attention to these naturalized refugees because after acquiring the citizenship humanitarian agencies usually quit the resettlement premises.
\end{abstract}

Key words: refugee, reintegration, naturalization, opportunities 


\section{Introduction}

Violent conflict remains one of the most important obstacles to reducing poverty, upholding human rights and achieving sustainable development in Africa. The spread of conflicts in Africa poses a threat to global security because it leads to large scale human displacement, environmental degradation and provides opportunities for international criminal and terrorist networks.

Entrenched and long running African conflicts such as those in Angola, Sudan and Somalia are now all but ignored. Meanwhile new wars have broken out. In the Great Lakes Region more than a dozen African nations have, in one way or another, been sucked into a series of interlocking conflicts since the mid 1990s.

According to the UNHCR, (2005) the number of refugees in Africa increased from 860,000 in 1968 to $6,775,000$ by 1992 . By the end of 2004, that number had dropped to 2,748,400 refugees, according to the United Nations High Commission for Refugees. Many refugees in Africa cross into neighboring countries to find haven. Often African countries are simultaneously countries of origin for refugees and countries of asylum for other refugees. The Democratic Republic of Congo, for instance, was the country of origin for 462,203 refugees at the end of 2004, but a country of asylum for 199,323 other refugees. Countries in Africa range from 5,000 and above, more refugees originated as of the end of 2004, arranged below. The largest numbers of refugees are from Sudan: 930, 612, Burundi: 485, 764, DRC: 462, 203, Somalia: 389, 272, Eritrea: 131, 119, Ethiopia: 63, 105, Chad: 52, 105 and Uganda: 31,963 .

Among these refugees and asylum seekers, there are those who entered in the country in large groups and those who did so individually in order to seek asylum and enjoy international protection. As a country, the United Republic of Tanzania continues to provide sanctuary to hundreds of thousands of refugees and asylum seekers from different neighboring countries. Her close proximity to refugee generating countries compounded with her long history of peace and stability, the generosity and hospitality of its' people has made Tanzania highly susceptible to large refugee influxes. Because of its humanitarian role in the provision of asylum and international protection to refugees, Tanzania has become an icon of asylum regime as manifested on her international obligation which she has pursued with endurance and dignity. The contribution that the country has made to this cause of humanity is invaluable yet indispensable. Forty five years down the line, the doors to the country continues to be open to bona vide refugees in need of protection and assistance (UNHCR, 2007).

According to UNHCR (2007) to date, the country provides asylum to about 526,800 refugees. Majority of these refugees come from Burundi, Democratic Republic of Congo (DRC), Somalia and some few asylum seekers from Ethiopia, Uganda, Kenya and Zimbabwe. The Refugee Department in the Ministry of Home Affairs is mandated by the government to address all matters pertaining to refugees during their stay in the country. From a legal perspective, the Refugee Act No.9 of 1998 together with the National Refugee Policy forms the fundamental tools of addressing refugee issues (UNHCR, 2007). 


\section{$\Lambda$ Macrothink}

Journal of Public Administration and Governance ISSN 2161-7104 2012, Vol. 2, No. 2

The history of refugee management and administration in the country has over the years evolved through two different stages. Initially refugees were settled in large settlements where they were provided with farming land with a view of enabling them become self sufficient in food production within two to three years upon their arrival. These settlements were established largely in the seventies, there are three old refugee settlements which host Burundian refugees who entered in the country since 1960's which are Ulyankulu in Tabora region, Katumba and Mishamo in Rukwa region. Another settlement is Chogo which is in Handeni District in Tanga region. The Chogo settlement hosts refugees from Somalia (the Bantu - Somali refugees) who fled the civil war in Somalia since 1990 (UNHCR, 2007)

The Chogo village is situated almost $22 \mathrm{~km}$ from Handeni district. It was established in 2003 after Somali refugees from the Mkuyu camp moved to Chogo. The Somali are refugees who were running out of their country of origin from ethnic violence.

UNHCR is also facilitating the local integration of 2,059 Somali refugees (as of 31 Dec 2007) living in the Chogo settlement in Tanga region, North of Dar es Salaam. The ancestors of many of these ethnic Bantu were taken to Somalia as slaves from present day Tanzania centuries ago. Based upon this historical link, the Government recognized these refugees on a group basis in the 1990s and, in 2003, offered them the option to locally integrate and become Tanzanian citizens. UNHCR has been providing support to the integration and naturalization process. So far some 1,020 naturalization certificates have been issued by UNHCR (2007).

\section{Literature Review}

\subsection{Reintegration of refugees into host communities}

In the last thirty years the international community has experienced many attempts, some successful and others less so as to move to peace and justice leading to conflict transformation which can be done through the notion of "reintegration" that usually answer the concerns by allowing individuals to return to their communities and be accepted as valued participants in the life of those communities (UNHCR, 2008).

There are close to 10,000 refugees in Ireland with rights similar to Irish nationals. Many are unable to return home and some may never do so. Many will make their permanent home in Ireland. Because of language barriers, unrecognized skills or qualifications and situations involving separated families, integration will not be easy for some refugees. This presents challenges and Ireland's statutory and voluntary agencies have been actively involved in assisting refugees and host communities to integrate. This has given to the challenges surrounding the integration of recognized refugees in Ireland. UNHCR has advocated for special support for refugees at the initial phases of their integration and has welcomed the approach of Ireland to facilitate access by refugees to mainstream services. UNHCR carried out research on the needs of refugees in the area of integration in a study called Mapping Integration in April 2009 (UNHCR, 2009).

In our experience, local authorities and communities have played a key role in the successful first phases of integration of refugees and their children in Ireland, in particular those local initiatives that dealt with language barriers, access to health, education, employment and 
participation in sports and other local leisure activities. Although it can have different meanings and definitions, there are common features in the approach to the integration of urban refugees between UNHCR and the European Union and its Member States, like Ireland. UNHCR's policy in this area is continually developing in tandem with policies being defined and shaped European-wide and internationally (UNHCR, 2009).

Refugees are granted a progressively wider range of rights and entitlements by the host state. Under the terms of the 1951 Refugee Convention, these include, for example, the right to seek employment, to engage in other income-generating activities, to own and dispose of property, to enjoy freedom of movement and to have access to public services such as education. The process whereby refugees gain and accumulate rights may lead to the acquisition of permanent residence rights and ultimately to the acquisition of citizenship in the country of asylum (United Nations, 1951).

Second local integration can be regarded as an economic process. For in acquiring the rights and entitlements referred to above, refugees also improve their potential to establish sustainable livelihoods, to attain a growing degree of self-reliance, and to become progressively less reliant on state aid or humanitarian assistance. In accordance with these indicators, refugees who are prevented or deterred from participating in the local economy, and whose standard of living is consistently lower than the poorest members of the host community, cannot be considered to be locally integrated, local integration is a social process, enabling refugees to live amongst or alongside the host population, without fear of systematic discrimination, intimidation or exploitation by the authorities or people of the asylum country. It is consequently a process that involves both refugees and the host population (United Nations, 1951).

The concept of local integration does not imply the assimilation of refugees in the society where that have found asylum. While the concept of assimilation is to be found in the 1951 UN Refugee Convention, the international community has always rejected the notion that refugees should be required or expected to abandon their own culture, so as to become indistinguishable from members of the host community. As one scholar has pointed out, integration is a more useful term than assimilation, suggesting as it does that refugees "maintain their own identity, yet become part of the host society to the extent that host population and refugees can live together in an acceptable way (UNHCR, 2005).

Taken from: "The local integration and local settlement of refugees: a conceptual and historical analysis", Jeff Crisp; Research Working Paper. How successfully members of migrant populations are integrating into European societies continues to be an important question in Europe, due in part to concerns to improve social cohesion and security. While this broad debate includes looking at the integration levels of a wide range of groups (ethnic minorities, immigrants and refugees) including second and third generation migrants born in Europe, anti-asylum rhetoric and the accompanying rise in hostility towards asylum seekers and refugees has increased the focus on the integration of refugees specifically (ECRE, 2005).

While it is widely acknowledged that the successful integration of refugees in European 
countries is of benefit to all (refugees, host communities, governments, economies, etc), the distinct climate of intolerance and racism in Europe is having a negative impact on the integration process of refugees. What is clear is that where refugees are marginalized through negative media reporting, political antipathy, insecure legal status, a lack of educational and employment opportunities, and/or hostility from local communities there is less integration. Those who feel threatened or excluded from the host society, instead of striving to belong, may seek to emphasize their difference through isolating themselves in their own communities and may also be more open to radical influences. What is also clear is that some policies of European states undermine integration, while many policies in place to promote it are not being effectively implemented. Due to the forced nature of their migration and their experiences, compared with other migrant groups, refugees will often have specific needs that have to be met in order to support their integration. They will often be one of the most vulnerable groups in society while also being the most resilient. It is therefore important that the special needs of refugees are recognized in integration policies and practice, including those of specific groups such as women and children, within an overall policy of mainstreaming (ECRE, 2005)

The debate in Europe often places the onus on the responsibilities of refugees to integrate them. ECRE and its member agencies stress the need to approach the integration of refugees as a dynamic two-way process which begins from the day a refugee arrives within the new host society. We consider it a continuous long term process enabling refugees and their communities to live in harmony with the host population of which they form a part. Refugee integration therefore places demands both on receiving societies and on the individuals and communities concerned (ECRE, 2005)

Until recently, urban refugees remained largely invisible to many donor governments, aid agencies, scholars, and advocates accustomed to assisting the refugees in camps and settlements (kibreab, 1996). But as Africa's cities grow and the displaced face the prospect of ever-longer periods in restrictive rural camps, refugees are becoming increasingly evident in the continent's urban centers and responses to urban refugees have been almost as diverse as refugees themselves (Kibreab, 1996). More so, when refugees are reintegrated and allowed to gain access to resources, have freedom of movement and can work alongside their hosts to pursue productive lives, they will be less dependent on aid, and better able to overcome the sources of tension and conflict in their host communities (Mary ,1999)

\section{Research design}

This study was focused on establishing the challenges and opportunities of reintegrating refugees into host communities. In order to achieve this, explanatory and descriptive research design was used in studying the problem under investigation.

Explanatory research design was used to discover new facts, insights and priorities for further research, describing at length of the phenomenon under study by giving explanations why things happen the way they are. This helped the researcher in giving out reasons on the relationship of the challenges and opportunities of reintegrating refugees into host communities. This research design presented answers beyond descriptive research design 


\section{Macrothink}

Journal of Public Administration and Governance

ISSN 2161-7104

2012, Vol. 2, No. 2

about the past problems. Descriptive research design was chosen due to the proximity and time bound to accomplish this research study as well as acquiring new knowledge about the study. It also portrayed the characteristics of the situation among the three groups in the Refugee resettlement.

\subsection{Study population}

Tanga region has a population of 1,642,015 people; Handeni district;248,633,Chogo village accommodates 420 people whereas Chogo refugee settlement hosts some 160 newly naturalized refugees who live and work together with Somali Bantu refugees around 160 and the neighboring communities 100 people. So this research comprised of Naturalized Somali Bantu refugees, Somali Bantu refugees, local people, and humanitarian agency members and resettlement officers.

Table 1 Population of People in Chogo Village

\begin{tabular}{lcc}
\hline POPULATION & NUMBER & PERCENTAGE \\
\hline Somali Bantu refugees & 160 & $39 \%$ \\
Naturalized Bantu refugees & 160 & $39 \%$ \\
Host communities & 100 & $22 \%$ \\
TOTAL & 420 & 100 \\
\hline
\end{tabular}

Source: Researcher data, 2011

\subsection{Sample Size}

While there are several ways of determining sample size including the rather abstract mathematical one, for simplicity/parsimony, the researcher decided to use the Slovenes formula in computing the sample size. The researcher used a sample size of 420 respondents. The respondents were stratified into one category; naturalized Somali Bantu refugees, local people, Somali Bantu refugees, resettlement officers and humanitarian agency.

Slovene's formula was used in computing the sample size;

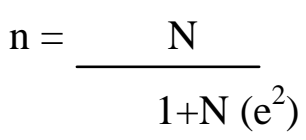

W here;

$$
\begin{aligned}
& \mathrm{n}=\text { the required sample size } \\
& \mathrm{N}=\text { the known population size, and } \\
& \mathrm{e}=\text { the level of significance, which is }=0.05
\end{aligned}
$$

$$
\begin{aligned}
\text { Sample size }(\mathrm{n})= & \frac{\mathrm{N}}{1+\mathrm{N}\left(0.05^{2}\right)} \\
\mathrm{n} & =\frac{420}{1+420\left(0.05^{2}\right)}
\end{aligned}
$$




$$
\begin{aligned}
& =\frac{420}{421(0.0025)} \\
& =\frac{420}{1.0525}
\end{aligned}
$$

Therefore $\quad \mathrm{n}=399$

The researcher included 399 respondents of which 133 were naturalized Somali Bantu refugees, 118 Somali Bantu refugees and 133 were local people, 5 resettlement officers and 10 humanitarian agency members. This is because these respondents gave a clear picture and an equal representation of the feedback of the refugees and host community of chogo refugee settlement.

Table 2 Sample Population of people in Chogo

\begin{tabular}{lcc}
\hline Respondent's & Number & $\%$ \\
\hline Naturalized Bantu Somali refugees & 133 & 33 \\
Somali Bantu Refugees & 118 & 30 \\
Host community & 133 & 33 \\
Resettlement officers & 5 & 1 \\
Humanitarian Agency & 10 & 2 \\
TOTAL & 399 & $100 \%$
\end{tabular}

Source: Researcher data, 2011

\subsection{Data analysis}

Likert scales also called summated rating scales which are among the most commonly used in social research which looks at a number of statements both positive and negative but it asks for simple "agreement" or "disagreement" with the item, the respondent is provided with a range of possible responses. Thus, an appropriate scoring scheme which is associated with each of the five possible responses like strongly agree $=5$, Agree $=4$, Undecided=3, Disagree $=2$, strongly disagree $=1$ (R.Cauvery, 2003). Therefore the researcher used the above described method of scaling in order to save time and energy which contributed to the existing stock of knowledge in this area of research.

The quantitative data was from questionnaires was analyzed using descriptive statistics and were tabulated into percentages and frequencies. Whereas the inferential statistics from the 
sampled population of Chogo village, was analyzed by correlation and regression analysis. The correlation technique is used to analyze the degree of relationship between two variables. Correlation analysis takes one step further by examining how various variables for further statistical analysis related, determines the strength and directions of the association between two variables which is very important because this piece of information forms the basis for selecting variables (Olive \& Abel, 2003). The researcher used regression analysis in finding out whether an independent variable predicted a given dependent variable

\section{Findings}

Key

$\begin{array}{lc}\text { Strongly agree } & 4.5-5 \\ \text { Agree } & 3.5-4.4 \\ \text { Undecided } & 2.5-3.4 \\ \text { Disagree } & 1.5-2.4 \\ \text { Strongly disagree } & 0.5-1.4\end{array}$

Table 3: showing descriptive Statistics for all the respondents

\begin{tabular}{lclll}
\hline Reintegration & $\begin{array}{c}\text { Mean for all } \\
\text { Respondent's }\end{array}$ & $\begin{array}{l}\text { Mean for } \\
\text { naturalized } \\
\text { Refugees }\end{array}$ & $\begin{array}{l}\text { Mean for } \\
\text { local people } \\
\text { Refugees }\end{array}$ & $\begin{array}{l}\text { Mean for } \\
\text { Somali } \\
\text { Refugees }\end{array}$ \\
\hline Seek employment & .4583 & 3.4000 & 4.0833 & 3.3125 \\
Income generating activities & 3.9657 & 4.0000 & 3.0833 & 4.8125 \\
Acquisition of citizenship & 3.3056 & 4.2667 & 3.2500 & 2.1250 \\
Reduce Language barrier & 3.2222 & 4.2000 & 4.0000 & 2.1250 \\
Health services & 3.0417 & 3.2000 & 1.5000 & 2.8125 \\
\hline
\end{tabular}

Source: Field data 2011

The above findings indicate that reintegration among Somali bantu refugees, naturalized Bantu refugees and local people can lead to the following opportunities in Chogo refugee settlement as shown in the table above evidenced by highest which is seek employment at (3.4583) which is strongly agree, acquisition of citizenship at (3.3056) which is agree, reduce language barrier (3.2222) meaning that all respondents agreed that reintegration leads to employment opportunities. The study found out that reintegration has played a significant role in providing opportunities for both the local people and the refugees as evidenced in the Table 3, above such as freedom of movement among the refugees and the local community by sharing the available resources like water, schools and dispensaries. However as observed above acquisition of citizenship is less with (2.1250) among the Somali refugees due to the fact these governmental officials in the resettlement, usually ask for money from Somali refugees in order to acquire the citizenship or else they keep on awaiting if they don't have enough money to bribe these government officials working under the ministry of Home 


\section{Macrothink}

Journal of Public Administration and Governance

ISSN 2161-7104

2012, Vol. 2, No. 2

affairs. On the other hand the reintegration among these two groups leads to interaction in different sharing knowledge, skills, cultural traditions, sensitization programmes and family issues such as marriage.

This agrees with the available literature that Refugees are granted a progressively wider range of rights and entitlements by the host state. Under the terms of the 1951 Refugee Convention, these include, for example, the right to seek employment, to engage in other income-generating activities, to own and dispose of property, to enjoy freedom of movement and to have access to public services such as education. The process whereby refugees gain and accumulate rights may lead to the acquisition of permanent residence rights and ultimately to the acquisition of citizenship in the country of asylum (United Nations, 1951).

Second local integration can be regarded as an economic process. For in acquiring the rights and entitlements referred to above, refugees also improve their potential to establish sustainable livelihoods, to attain a growing degree of self-reliance, and to become progressively less reliant on state aid or humanitarian assistance. In accordance with these indicators, refugees who are prevented or deterred from participating in the local economy, and whose standard of living is consistently lower than the poorest members of the host community, cannot be considered to be locally integrated, local integration is a social process, enabling refugees to live amongst or alongside the host population, without fear of systematic discrimination, intimidation or exploitation by the authorities or people of the asylum country. It is consequently a process that involves both refugees and the host population (United Nations, 1951)

Table 4 showing Correlation contributions of reintegration among all respondents

\begin{tabular}{llllllll}
\hline & Reintegration & Employment & Income & Freedom & Citizenship & language & Health \\
\hline & 1.000 & & & & & \\
Employment & -188 & 1.000 & & & & & \\
Income & .377 & -104 & 1.000 & & & & \\
Freedom & .007 & -057 & .288 & 1.000 & & \\
Citizenship & .349 & .220 & .124 & -123 & 1.000 & \\
Language & .185 & .058 & -013 & .242 & .340 & 1.000 & \\
Health & .405 & -009 & .151 & .074 & .456 & .292 & 1.000 \\
\hline
\end{tabular}

Source: Field data 2011 


\section{Macrothink}

Journal of Public Administration and Governance

ISSN 2161-7104

2012, Vol. 2, No. 2

From the correlation a analysis above with the correlation coefficients of $0.405,0.349$, 0.377 of the total sample reported that access to health services, acquisition of citizenship, income generating activities among the opportunities got from the reintegration among refugees and local community as shown in table 4 .The respondents said that these are the major opportunities brought by reintegration among local people, Somali Bantu refugees and the naturalized Somali Bantu refugees.

\section{Regression Table 5 showing the opportunities of reintegration among all respondents}

$\begin{array}{llll}\text { Unstandardized } & \begin{array}{l}\text { Standardized } \\ \text { Coefficients }\end{array} & & \\ \text { Coefficients } & \text { t } & \text { Sig. } \\ \text { B Std. Error } & \text { Beta } & & \end{array}$

$\begin{array}{lccccc}\text { (Constant) } & & & & & \\ {\text { Employ } \mathrm{x}_{1}} & -207 & .105 & -.207 & -1.979 & .052 \\ \text { Income }_{2} & .310 & .103 & .328 & 3.011 & .004 \\ \text { Freedomx }_{3} & -019 & .018 & -116 & -1.021 & .311 \\ \text { Citizensx }_{4} & .164 & .105 & .197 & 1.570 & .121 \\ \text { Languax }_{5} & .078 & .098 & .091 & .792 & .431 \\ \text { Health } \mathrm{x}_{6} & .214 & .101 & .246 & 2.123 & .038\end{array}$

A Dependent Variable: reintegration Source: Field data 2011

$\mathrm{Y}=\mathrm{a}+\mathrm{bx}_{1}+\mathrm{cx}_{2}+\mathrm{dx}_{3}+\mathrm{ex}_{4}+\mathrm{fx}_{5}+\mathrm{gx}_{6}$

$\mathrm{Y}=2.033+0.310 \mathrm{x}_{2}+0.214 \mathrm{x}_{6}+0.164 \mathrm{x}_{4}+0.078 \mathrm{x}_{5}+207 \mathrm{x}_{1}-019 \mathrm{x}_{3}$

From equation two above the highest beta coefficient is $\mathrm{C}$ income generating activities at (0.310), $\mathrm{g}$ access to health Services at (0.214) and e acquisition of citizenship at (0.164).As shown above one percent increase to income generating activities increases opportunities for reintegration by $0.310 \%$ and one percent increase to Access to health services increases opportunities for reintegration by $0.214 \%$. Since the beta coefficient is negative it implies that one percent decrease in employment opportunities hinders the reintegration process by $0.207 \%$

It was found out by the study that reintegration have provided most of the Somali refugees with the acquisition of Tanzanian citizenship after being naturalized most of these refugees apply for the citizenship of Tanzania from the ministry of home affairs then become Tanzanian citizens. However it was revealed by the study that some Somali refugees after acquiring citizenship they move from the resettlement and go to stay in urban towns like Arusha,Moshi,Dodoma, Mwanza and Dar es salaam e.t.c. and others go to kakuma camp in Kenya to enjoy the humanitarian aid. Added to the above, as evidenced in the table above that freedom of movement at 0.19 among refugees and the host communities is low which also hinders the reintegration process due to the low rate of interactions. it was noted that to 
some Somali refugees never wanted to acquire the Tanzania citizenship where some had even stayed for more that 20 year without applying for the citizenship claiming they want to go back to their homeland Somalia.

Table 6 showing descriptive Statistics for all the respondents

Contributions

Mean for all Mean for

Mean for

Mean for

Respondents'

local people

Naturalized

Somali refugees

Training Heath services

3.2951

2.5574

3.7333

2.5000

Shelter services

3.6557

3.2951

3.0000

3.1667

Forests planted by environment 2.1967

2.6557

2.0667

3.1667

Vocational training school 3.8033

2.1967

4.4000

3.2222

Rehabilitation of roads \&

4.1475

3.8033

4.8667

3.5000

Other infrastructure

$\begin{array}{llllr}\text { Business training } & 1.6885 & 4.1475 & 1.3333 & 3.2967 \\ \text { Reintegration } & 4.5028 & 4.2951 & 4.6667 & 4.5466\end{array}$

\section{Source: Field data, 2011}

Humanitarian agencies were found playing a great role in helping the refuge settlement particularly Chogo refugee resettlement which was under study, the field results presented thus; rehabilitation of roads and other infrastructure schools with 4.1475, reintegration with 4.2951, vocational training schools with 3.8033 of the total sample. Added to the above is that the study found out that humanitarian agency has played a significant role in the reintegration process among the refugees and host community in Chogo village as evidenced by (4.2951).

This agrees with the literature that Humanitarian agencies like UNHCR and REDESO play a big a role curbing down the challenges among people's lives. It concurs with this study by UNHCR, 2009 there are close to 10,000 refugees in Ireland with rights similar to Irish nationals. Many are unable to return home and some may never do so. Many will make their permanent home in Ireland. Because of language barriers, unrecognized skills or qualifications and situations involving separated families, integration will not be easy for some refugees. This presents challenges and Ireland's statutory and voluntary agencies have been actively involved in assisting refugees and host communities to welcomes the emphasis that the Minister of State for Integration has given to the challenges surrounding the integration of recognized refugees in Ireland. UNHCR has advocated for special support for refugees at the initial phases of their integration and has welcomed the approach of Ireland to facilitate access by refugees to mainstream services. UNHCR carried out research on the needs of refugees in the area of integration in a study called Mapping Integration in April 
2009.

In our experience, local authorities and communities have played a key role in the successful first phases of integration of refugees and their children in Ireland, in particular those local initiatives that dealt with language barriers, access to health, education, employment and participation in sports and other local leisure activities. Although it can have different meanings and definitions, there are common features in the approach to the integration of urban refugees between UNHCR and the European Union and its Member States, like Ireland. UNHCR's policy in this area is continually developing in tandem with policies being defined and shaped European-wide and internationally (UNHCR, 2009).

Essentially, UNHCR sees integration as a two-way process involving efforts by the refugee and the host country to create the conditions that will allow individual refugees to start rebuilding their lives. In these efforts, it is the host country that must take the lead role and communicate its expectations for integration. UNHCR's definition of integration flows from the 1951 Refugee Convention and a number of the agency's Executive Committee's conclusions on durable solutions and local integration. Three key elements have been identified within integration, including the fact it involves legal challenges, questions around economic rights and self-reliance, and others concerning social and cultural integration. To ensure success, all three aspects must be supported by the host State (UNHCR, 2009).

Added to the above findings indicated that reintegration among Somali bantu refugees, naturalized bantu refugees and local people can lead to the following opportunities in Chogo refugee settlement as shown in the table 4.10 freedom of movements, acquisition of citizenship, employment opportunities meaning that all respondents agreed that reintegration leads to employment opportunities among the refugees and the host communities. Thus, according to the study reintegration leads to easy access to health Services and reducing language barrier among the naturalized refugees and the host communities.

\section{Conclusions}

The researcher concluded that reintegration has played a significant role in providing opportunities for both local people and the refugees such as freedom of movement among the refugees and the local community by sharing the available resources like water, schools and dispensaries. On the other hand the reintegration among these two groups leads to interaction in different ways of sharing knowledge, skills, cultural traditions, sensitization programmes and family issues such as marriage.

\section{Recommendations}

According to the researcher recommended that the ministry of home affairs should enforce the acquisition of citizenship by some of these refugees who are reluctant to acquire citizenship claiming that they want to keep enjoying the privileges until they are repatriated back home. In the long run, the government should consider sensitization programmes among refugees and the host community towards the opportunities of reintegration rather than allocating the integrated refugees land only.

More so, the government of Tanzania should pay attention to these naturalized refugees 
because after acquiring the citizenship humanitarian agencies usually quit the resettlement premises. And due to this these naturalized refugees face a lot of challenges after these humanitarian agencies withdrawing from assisting refugees for example when it comes to traditional differences in cultural practices and income generating activities.

\section{References}

Akinboye, S.O. and Ottoh, .F.O. (2005). A Systematic Approach to International Relations. Lagos: Concept Publications

McGrew, A. and Lewis, P. (1992). Global Politics. Polity Press: Cambridge

Brock G.\& Brig house .H,(2005) the political philosophy of cosmopolitanism. Cambridge University Press.

Betts. A. (2004). "International Cooperation and the Targeting of Development Assistance for Refugee Solutions: Lessons from the 1980's". New Issues in Refugee Research: Working Paper n. 107 (September).

Betts. A. (2005). "International Cooperation between North and South to Enhance Refugee Protection in Regions of Origin". RSC, Working Paper n. 25 (July).

Baker J. (1995). "Refugee and Labour Movements in Sub-Saharan Africa: A review”. Studies on Emergencies and Disaster Relief.

Samson S. W, (2007) Traditional Mechanisms of Conflict Resolution in Southern Sudan Workshop on "Resources, Governance Structures, and Civil War," Joint Sessions of Workshops of the European Consortium for Political Research, Uppsala, Sweden, 13-18 April, and the 100th Annual Meeting of the American Political Science Association, Chicago, IL, USA, 2-5 September United Nations High Commissioner for Refugees (UNHCR), "2007, 2004\&2009 Global Trends: Refugees, Asylum-seekers, Returnees, Internally Displaced and Stateless Persons, ” June.

UNHCR, (2002\&2003) New issues in refuge research, No 57 Geneva evaluation and policy analysis unit, responding to protracted refugee situations: a case study Liberian refuge in Ghana - Geneva Evaluation and policy analysis in it, UNHCR, (2004\&2005). "Map. Ethnicity of Sudanese Refugees in Eastern Chad”. Geneva, Switzerland. UNHCR, (2004) Global Refugee Trends. Geneva, Switzerland.

Whitaker B., (1999). "Changing Opportunities: Refugees and Host Communities in western Tanzania”. New Issues in Refugee Research: Working Paper No. 11 (June).

Women's Commission for Refugee Women and Children (2005). Don't Ever Forget Us: the Education and Gender-based Violence Protection Needs of Adolescent Girls from Darfur in Chad. New York. 


\section{$\triangle$ Macrothink}

\section{Appendix I}
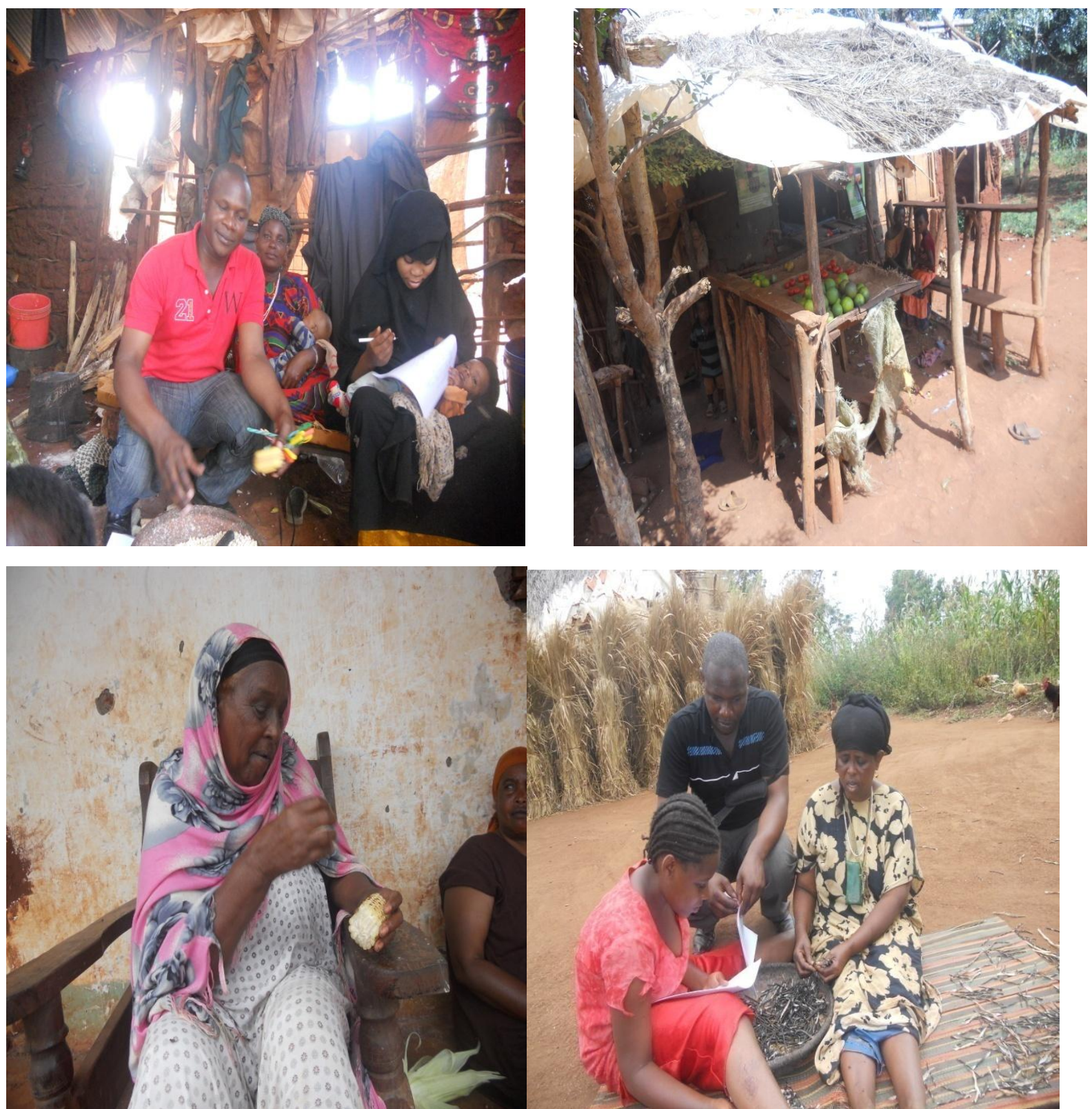

Field Photograph by the Researcher, June, 2011

A picture showing how reintegration of Somali refugee and Somali Bantu refugees into local people, how they are living together in an acceptable and harmonious way as peace prevails in CHOGO resettlement.

\section{Appendix II}



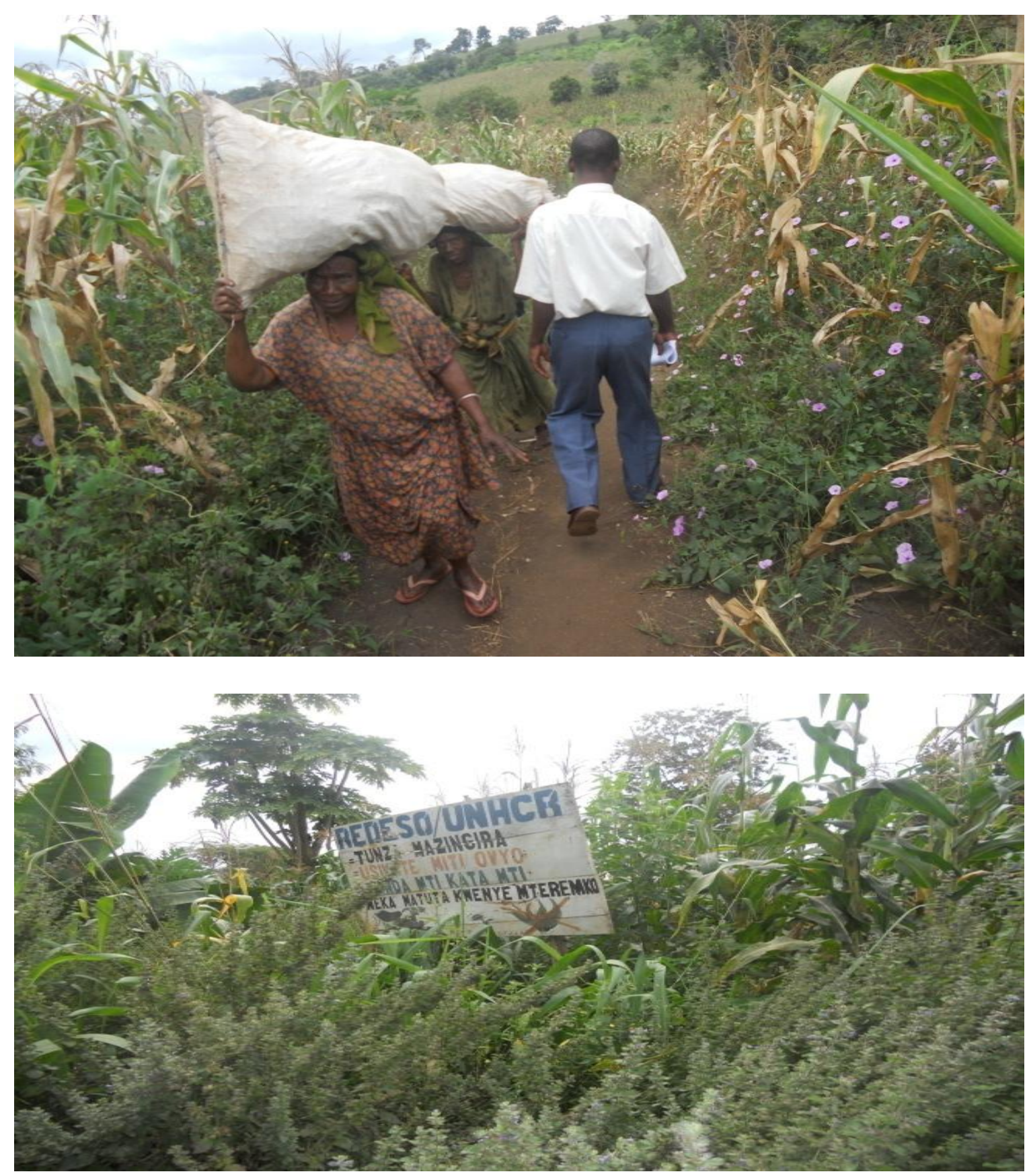

Field Photograph by the Researcher, June, 2011

A picture showing how REDESO and UNHCR support farmers in the resettlement through sensitizing them about modern practices of agriculture. 